Original Article

\title{
Diversity of the Anisoptera \& Zygoptera (Odonata: Insecta) of Swat, Pakistan
}

\author{
Diversidade de Anisoptera e Zygoptera (Odonata: Insecta) de Swat, Paquistão

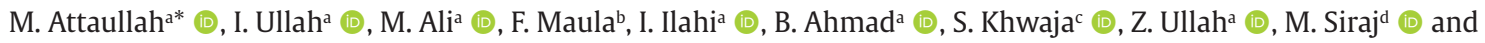 \\ S.M.M. Raheele (D) \\ aniversity of Malakand, Department of Zoology, Chakdara, Dir Lower, Pakistan \\ ${ }^{\mathrm{b}}$ Agricultural Research Institute, Entomology Section, Mingora, Swat, Pakistan \\ cFederal Urdu University of Arts, Science \& Technology, Department of Zoology, Karachi, Pakistan \\ dAbbottabad University of Science and Technology, Department of Zoology, Abbottabad, Pakistan \\ 'Govt. Sadiq Abbas Post Graduate College, Department of Zoology, Bahawalpur, Pakistan
}

\begin{abstract}
Odonates are important biological control agents for the control of insect pests and insect disease vectors of medical and veterinary importance. The present study was conducted to evaluate the odonate fauna of Swat, Pakistan from March to October 2019. A total of 200 specimens of odonates were collected from diverse habitats. The collected specimens of the order Odonata belonged to 5 families, three families of suborder Anisoptera namely Libellulidae, Gomphidae and Aeshnidae while two families of suborder Zygoptera (Chlorocyphidae and Coenagrionidae). The specimens were categorized into 12 genera and 22 species. Libellulidae was the dominant family $(n=138)$ accounting for $69 \%$ of the odonate fauna. Orthetrum was the dominant genus $(n=73)$ of suborder Anisoptera accounting for $36.5 \%$ of the odonate fauna. The least dominant genera were Anax, Paragomphus and Rhyothemis ( $\mathrm{n}=5$ each) accounting each for $2.5 \%$ of the odonate fauna. In Zygoptera, the dominant genus was Ceriagrion (12.5\%) and the least dominant genus was Ischnura (6\%). Pantala flavescens (Fabricius, 1798) was the most abundant odonate species in the study area recorded from all surveyed habitats. Shannon Diversity Index $(\mathrm{H})$ was 2.988 and Simpson Diversity Index (D) was 0.95 for the collected odonate fauna. The highest abundance of Odonata was recorded in August, September and May while no odonate species were recorded in January, February, November and December. Lotic water bodies were the most suitable habitats with abundant odonate fauna. Anax immaculifrons (Rambur, 1842) was the largest sized odonate species having a wingspan of $53.2 \pm 1.63 \mathrm{~mm}$ and body length of $56.3 \pm 0.4 \mathrm{~mm}$. The present study shows the status of odonate fauna of Swat, Pakistan in diverse habitats and seasonsonal variation throughout the year. Further work is recommended to bridge the gaps in the existing literature.
\end{abstract}

Keywords: dragonflies, damselflies, Libellulidae, Gomphidae, Aeshnidae.

\begin{abstract}
Resumo
Odonatos são importantes agentes de controle biológico para o controle de insetos-praga e vetores de doenças de insetos de importância médica e veterinária. O presente estudo foi conduzido para avaliar a fauna de odonatos de Swat, Paquistão, de março a outubro de 2019. Um total de 200 espécimes de odonatos foi coletado em diversos habitats. Os espécimes coletados da ordem Odonata pertenciam a cinco famílias, três famílias da subordem Anisoptera, a saber, Libellulidae, Gomphidae e Aeshnidae, enquanto duas famílias eram da subordem Zygoptera (Chlorocyphidae e Coenagrionidae). Os espécimes foram classificados em 12 gêneros e 22 espécies. Libellulidae foi a família dominante ( $n=138$ ), respondendo por $69 \%$ da fauna de odonatos. Orthetrum foi o gênero dominante $(n=73)$ da subordem Anisoptera, responsável por 36,5\% da fauna de odonatos. Os gêneros menos dominantes foram Anax, Paragomphus e Rhyothemis ( $\mathrm{n}=5$ cada), representando cada um 2,5\% da fauna de odonatos. Em Zygoptera, o gênero dominante foi Ceriagrion (12,5\%), e o gênero menos dominante foi Ischnura (6\%). Pantala flavescens (Fabricius, 1798) foi a espécie de odonato mais abundante na área de estudo, registrada em todos os habitats pesquisados. O Índice de Diversidade de Shannon $(\mathrm{H})$ foi de 2,988, e o Índice de Diversidade de Simpson (D) foi de 0,95 para a fauna de odonatos coletados. A maior abundância de Odonata foi registrada em agosto, setembro e maio, enquanto nenhuma espécie de Odonata foi registrada em janeiro, fevereiro, novembro e dezembro. Corpos d'água lóticos foram os habitats mais adequados, com abundante fauna de odonatos. Anax imaculifrons (Rambur, 1842) foi a espécie de odonato de maior tamanho, com envergadura de $53,2 \pm 1,63 \mathrm{~mm}$ e comprimento do corpo de $56,3 \pm 0,4 \mathrm{~mm}$. O presente estudo mostrou o status da fauna de odonatos de Swat, Paquistão, em diversos habitats e variação sazonal ao longo do ano. Recomenda-se trabalho adicional para preencher as lacunas na literatura existente.
\end{abstract}

Palavras-chave: libélulas, libelinhas, Libellulidae, Gomphidae, Aeshnidae.

*e-mail: m.attaullah@uom.edu.pk; attaullah.ms@gmail.com

Received: May 7, 2021 - Accepted: June 17, 2021 


\section{Introduction}

Anisoptera (dragonflies) and Zygoptera (damselflies) (Odonata: Insecta) represent a diverse group of insects having 5740 described species worldwide (Johari and Jain, 2021). Odonates are beneficial insects and play an important role in pest management both as nymphs and adults (Trueman and Rowe, 2009; Ilahi et al., 2019). They are easily recognized by a long slender abdomen, large eyes, short antennae, and long membranous wings with beautifully colored bodies (Nair, 2011). The male odonates are usually brightly colored than females. Odonates tend to inhabit both lotic and lentic water bodies. They are mostly found around the fresh water, and act as biological indicators. They are good ecological indicators of the ecosystem (Johnson and Triplehorn, 2005). The presence of Odonata on water shows its pollution-free status.

Odonates are predators both in the larval stage as well as adult stage; their larvae are voracious feeders and possess large retractable labium for capturing prey. They are known to feed on mosquito larvae, protozoans and small crustaceans (Irshad, 2008) tadpoles, fish fry and even larvae of other odonates (Boyd, 2005). Adults normally feed on small flying insects like gnats, moths and noxious flies (Fraser, 1933) and act as important biocontrol agents. Odonates act as predators of mosquito larvae and play an important role in regulation of mosquito population (Knight and Larsen, 2004). Due to predatory potential against mosquito larvae, they are used in the ecofriendly control of mosquito larvae (Mitra, 2002). The nymphs of Odonata play important role in the regulation of mosquito population (Din et al., 2013) and are very sensitive to environmental pollutants (Clark and Samways, 1996). The adults mostly feed on the harmful insects, which infest orchard and forest, and maintain forest and agricultural fields (Mitra, 2002).

Inventories of target taxa provide good data. Odonates are diverse in habitats, but some species are specific to habitats which make them useful as biological indicators (Clark and Samways, 1996; Samways and Steytler, 1996). Many species of Odonata are specialists which are sensitive to changes in habitats and become extinct than generalist species (Suhonen et al., 2014). Anisoptera which includes the dragonflies are larger in size and are more resistant to disturbance, do not require riparian vegetation and found mostly in open areas to absorb the sunlight (DeMarco Junior and Resende, 2002). Urbanization is one of the major causes for the loss of odonate diversity (Willigalla and Fartmann, 2012).

The odonates fauna of Pakistan has been less investigated than their neighbor countries. Studies on Odonate fauna from some parts of Pakistan include Rafi et al. (2009), Zia et al. (2009, 2011, 2019), Din et al. (2013), Perveen et al. (2014), Chaudhry et al. (2016) and Fazlullah et al. (2016). The present study was aimed to evaluate the diversity of the suborders Anisoptera and Zygoptera of the order Odonata in Swat, Pakistan across diverse habitats and in different seasons of the year.

\section{Materials and Methods}

\subsection{Study area}

The present study was conducted at District Swat, Pakistan. Swat is located at $35.2227^{\circ} \mathrm{N}$ and $72.4258^{\circ} \mathrm{E}$ with a total area of $5337 \mathrm{Km}^{2}$. Diverse habitats including running and stagnant freshwater bodies, rice fields, marshes, low and high-altitude mountainous areas were surveyed for the collection of odonate fauna. The habitats surveyed for the collection of odonate fauna are given (see Figure 1).

\subsection{Sample collection}

Collection of dragonflies and damselflies was made from March to October 2019 through aerial nets; the sites were sampled in sunny days between 10:00 am and 02:00 pm. Odonate abundance was less in the streams having pollutants and industrial chemical discharges compared with less polluted and unpolluted freshwater bodies.

\subsection{Killing and preservation}

The collected specimens were placed in killing bottles having Potassium Cyanide. After killing and rigor mortis, the specimens were properly pinned in the setting boards, labelled, and mounted in the entomological boxes. Naphthalene balls were placed in the boxes to prevent them from pests. All these activities were carried out in the Agriculture Research Institute, Takhta Band, Swat.

\subsection{Identification}

Identification of the specimens was done in the Entomology Laboratory, Department of Zoology, University of Malakand, Pakistan with the help of taxonomic keys and previous literature by Nair (2011), Fraser (1933) and through internet surfing. Morphological characters of the adult odonate specimens were studied with the help of Lx 400 binocular microscope.

\subsection{Morphometric measurements}

Wingspan and body length of the collected specimens were calculated in millimeters ( $\mathrm{mm}$ ) with the help of a ruler. Mean values of the wingspan and body length of all specimens in each species were calculated and tabulated (as shown in Table 1).

\subsection{Data analysis}

Data was calculated using MS Excel 2016. Shannon diversity index $(\mathrm{H})$ and Simpson diversity index (D) were calculated for the odonate fauna using the formulae given in the results section. Morphometrics of the identified species were calculated and their mean values with standard deviations are tabulated in the results section.

\section{Results}

The collected specimens $(n=200)$ of Odonata were categorized into 22 species, belonging to 5 families. Suborder Anisoptera was represented by families Gomphidae, Libellulidae and Aeshnidae. Family Gomphidae 

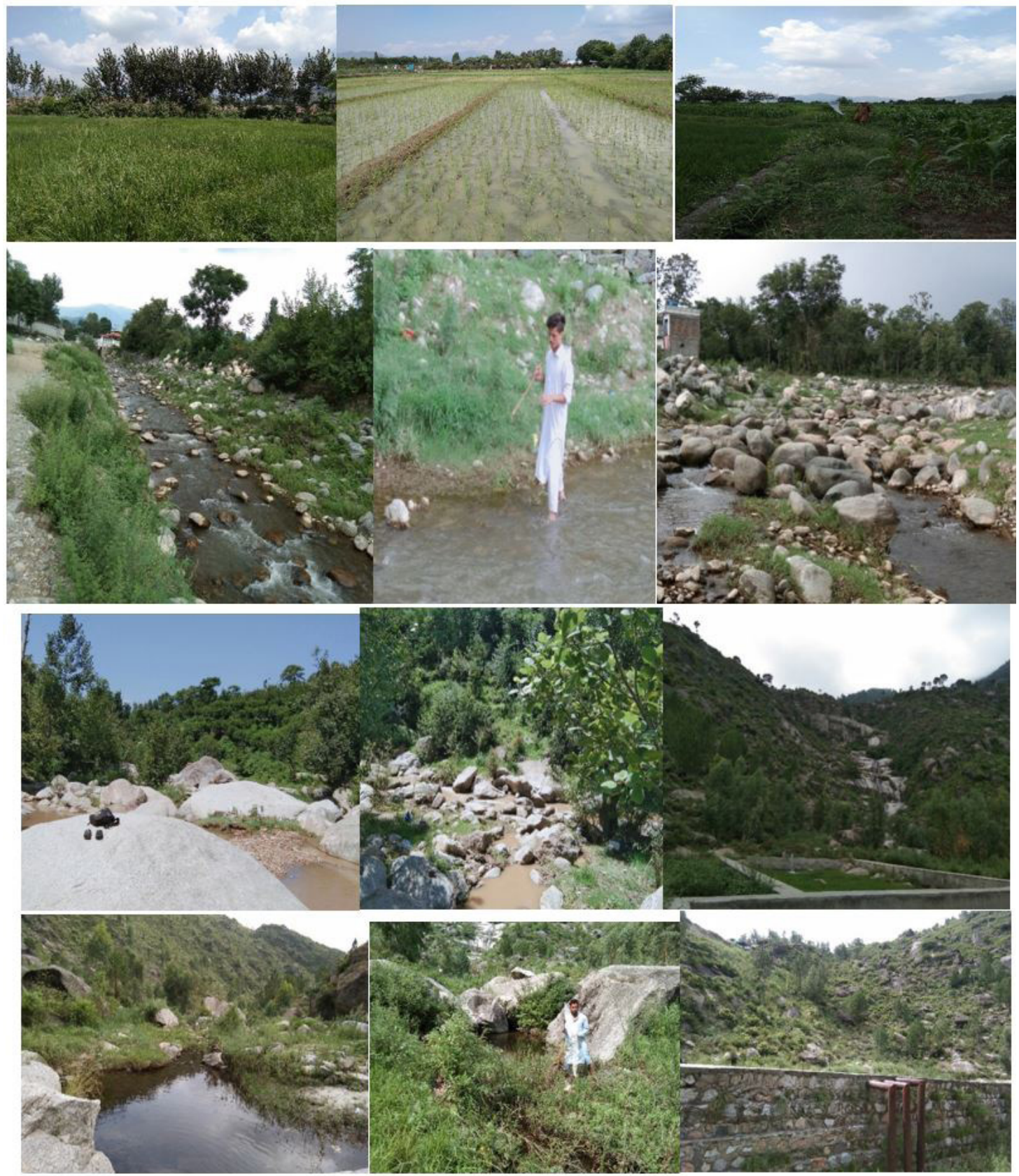

Figure 1. Habitats surveyed for collection of Odonata at Swat, Pakistan.

(clubtails) was represented by the common hooktails Paragomphus lineatus (Selys 1850) in which the males were medium-sized (32-37 mm long with a wingspan of 24-27 mm, yellow and black dragonflies identified by the lateral expansions of 8th and 9th abdominal segments and diagnostic hook-shaped superior anal appendages. The females were somewhat similar in size but duller in color lacking lateral expansions to abdomen. Family Libellulidae (Skimmers or perches) was the dominant family recorded from diverse habitats in the present study. The males are often brightly colored. The habitat choice varies hugely and encompasses almost all forms of wetlands including garden ponds, marshes, lakes, rivers and even seasonal rainwater puddles. Libellulidae was represented by Acisoma panorpoides (Rambur, 1842), Orthetrum cancellatum (Linnaeus, 1758), 0. pruinosum (Bermeister, 1839), 0. testaceum (Bermeister, 1839), O. sabina (Drury, 1770), 0. triangulare (Selys, 1878), Rhyothemis variegate (Linnaeus, 1763), Pantala flavescens (Fabricius, 1798), Rhodothemis rufa (Rambur, 1842), Palpopleura sexmaculata (Fabricius, 1787), Trithemis aurora (Bermeister, 1839), Trithemis festiva (Rambur, 1842) and O. luzonicum (Brauer, 1868). 
Table 1. Classification and morphometrics of the odonate fauna of Swat, Pakistan.

\begin{tabular}{|c|c|c|c|c|c|c|}
\hline S.No. & Species & Family & Suborder & $\mathbf{n}$ & $\begin{array}{l}\text { WS }(\mathrm{mm}) \\
\text { Mean } \pm \text { SD }\end{array}$ & $\begin{array}{l}\text { BL }(\mathrm{mm}) \\
\text { Mean } \pm S D\end{array}$ \\
\hline 1. & $\begin{array}{l}\text { Paragomphus } \\
\text { lineatus }\end{array}$ & Gomophidae & Anisoptera & 05 & $27.3 \pm 0.75$ & $34.76 \pm 0.45$ \\
\hline 2. & $\begin{array}{c}\text { Acisoma } \\
\text { panorpoides }\end{array}$ & Libellulidae & & 10 & $18.5 \pm 1.52$ & $17.3 \pm 0.9$ \\
\hline 3. & $\begin{array}{l}\text { Orthetrum } \\
\text { triangulare }\end{array}$ & Libellulidae & & 10 & $40 \pm 1.18$ & $32 \pm 1.5$ \\
\hline 4. & O. pruinosum & Libellulidae & & 15 & $54.8 \pm 1.64$ & $30 \pm 1.12$ \\
\hline 5. & O. testaceum & Libellulidae & & 10 & $34 \pm 1.56$ & $33 \pm 2.04$ \\
\hline 6. & O. glaucum & Libellulidae & & 04 & $40 \pm 1.18$ & $34.76 \pm 0.45$ \\
\hline 7. & O. luzonicum & Libellulidae & & 10 & $31 \pm 1.13$ & $30 \pm 0.9$ \\
\hline 8. & O. cancellatum & Libellulidae & & 09 & $34 \pm 1.56$ & $33.7 \pm 1.67$ \\
\hline 9. & O. sabina & Libellulidae & & 10 & $34.7 \pm 1.56$ & $33 \pm 2.04$ \\
\hline 10. & $\begin{array}{l}\text { Rhyothemis } \\
\text { variegate }\end{array}$ & Libellulidae & & 05 & $32 \pm 1.16$ & $24 \pm 1.54$ \\
\hline 11. & Pantala flavescens & Libellulidae & & 20 & $36.47 \pm 3.34$ & $30.76 \pm 2.18$ \\
\hline 12. & $\begin{array}{l}\text { Palpopleura } \\
\text { sexmaculata }\end{array}$ & Libellulidae & & 10 & $17 \pm 0.86$ & $15.5 \pm 1.04$ \\
\hline 13. & Trithemis aurora & Libellulidae & & 05 & $32.2 \pm 1.8$ & $24 \pm 0.89$ \\
\hline 14. & $\begin{array}{l}\text { Crocothemis } \\
\text { servilia }\end{array}$ & Libellulidae & & 10 & $30.7 \pm 0.78$ & $26.5 \pm 1.11$ \\
\hline 15. & O. taeniolatum & Libellulidae & & 05 & $40.2 \pm 0.5$ & $39 \pm 0.73$ \\
\hline 16. & Trithemis festiva & Libellulidae & & 05 & $32 \pm 1.16$ & $26.5 \pm 1.11$ \\
\hline 17. & $\begin{array}{c}\text { Anax } \\
\text { immaculifrons }\end{array}$ & Aeshnidae & & 05 & $53.2 \pm 1.63$ & $56.3 \pm 0.4$ \\
\hline 18. & $\begin{array}{l}\text { Rhinocypha } \\
\text { quadrimaculata }\end{array}$ & Chlorocyphidae & Zygoptera & 10 & $27.3 \pm 0.75$ & $23 \pm 1.73$ \\
\hline 19. & R. bisignata & Chlorocyphidae & & 05 & $18 \pm 1.26$ & $24 \pm 1.53$ \\
\hline 20. & Ischnura aurora & Coenagrionidae & & 12 & $17 \pm 1.09$ & $32 \pm 1.16$ \\
\hline 21. & $\begin{array}{c}\text { Ceriagrion } \\
\text { coromandelianum }\end{array}$ & Coenagrionidae & & 15 & $24 \pm 0.89$ & $34.7 \pm 2.1$ \\
\hline 22. & C. olivaceum & Coenagrionidae & & 10 & $14.8 \pm 1.49$ & $20 \pm 1.29$ \\
\hline
\end{tabular}

Legend: n: number of specimens; WS: Wingspan; BL: Body Length; mm: milli meter.

Morphometric parameters of all collected specimens were carried out and the values (Mean \pm Standard Deviation) were tabulated (as shown in Table 1).

Suborder Zygoptera was represented by families Chlorocyphidae and Coenagrionidae. Chlorocyphidae (stream jewels) are characterized by large prominent eyes and are medium sized having projecting nose. Their wings are longer than their abdomens. Sexual dimorphism between male and female is common, males have colorful metallic patches on their wings while females have transparent wings. They mostly inhabit flowing streams. Species belonging to family Chlorocyphidae in the present study were Rhinocypha quadrimaculata and Rhinocypha bisignata (as shown in Table 1). Rhinocypha quadrimaculata (Selys, 1853) is commonly known as black emperor because of the black coloration with pinkish triangular mid thoracic patches. They are medium sized with males $25 \mathrm{~mm}$ long with wing length of $27 \mathrm{~mm}$ while females are $25 \mathrm{~mm}$ long with a wingspan of $31 \mathrm{~mm}$. Rhinocypha bisignata (Selys, 1853) is commonly known as stream ruby. Family Coenagrionidae (marsh darts) was represented by three species, Ceriagrion coromandelianum, Ceriagrion olivaceum and Ischnura aurora. Ceriagrion coromandelianum (Fabricius, 1798 ) is a medium-sized damselfly having yellowish-green eyes. Thorax is green above and yellowish green on the sides with yellow abdomen. Females are more robust having dull coloration. Males are $20 \mathrm{~mm}$ with a wingspan of 24-26 mm. Females are $16 \mathrm{~mm}$ long with wingspan of $22 \mathrm{~mm}$. Ceriagrion olivaceum (Laidlaw, 1914) is a medium sized damselfly having brown capped greenish eyes, thorax green in color and paler on the sides. Ischnura aurora (Brauer 1865) is also known as aurora bluetail. A small 
Table 2. Seasonal variation of the odonate fauna of Swat, Pakistan.

\begin{tabular}{|c|c|c|c|c|c|c|c|c|c|c|c|c|c|c|}
\hline S.No. & Species & Jan & Feb & Mar & Apr & May & June & July & Aug & Sep & Oct & Nov & Dec & Total \\
\hline 1 & P. lineatus & -- & -- & -- & -- & -- & -- & -- & 2 & 1 & -- & -- & -- & 05 \\
\hline 2 & A. panorpoides & -- & -- & -- & -- & -- & -- & -- & 5 & 5 & -- & -- & -- & 10 \\
\hline 3 & O. triangulare & -- & -- & -- & -- & 5 & 5 & -- & -- & -- & -- & -- & -- & 10 \\
\hline 4 & O. pruinosum & -- & -- & -- & -- & 5 & 2 & -- & 3 & 5 & -- & -- & -- & 15 \\
\hline 5 & O. testaceum & -- & -- & -- & 4 & 3 & -- & 2 & 1 & -- & -- & -- & -- & 10 \\
\hline 6 & O. luzonicum & -- & -- & -- & -- & 5 & -- & -- & 2 & 3 & -- & -- & -- & 10 \\
\hline 7 & O. cancellatum & -- & -- & -- & -- & 3 & 2 & 2 & 2 & -- & -- & -- & -- & 09 \\
\hline 8 & O. sabina & -- & -- & -- & -- & 2 & 2 & 1 & 3 & 2 & -- & -- & -- & 10 \\
\hline 9 & P. flavescens & -- & -- & -- & -- & -- & -- & 5 & 9 & 6 & -- & -- & -- & 20 \\
\hline 10 & T. aurora & -- & -- & -- & -- & 1 & 2 & -- & 1 & 1 & -- & -- & -- & 05 \\
\hline 11 & P. sexmaculata & -- & -- & -- & -- & -- & -- & -- & 3 & 7 & -- & -- & -- & 10 \\
\hline 12 & R. variegate & -- & -- & -- & -- & 2 & -- & -- & 1 & 2 & -- & -- & -- & 05 \\
\hline 13 & T. festiva & -- & -- & -- & -- & -- & -- & -- & 2 & 1 & 2 & -- & -- & 05 \\
\hline 14 & O. taeniolatum & -- & -- & -- & 1 & 2 & 1 & -- & -- & 1 & -- & -- & -- & 05 \\
\hline 15 & O. glaucum & -- & -- & -- & -- & 1 & 1 & -- & 1 & 1 & -- & -- & -- & 04 \\
\hline 16 & C. servilia & -- & -- & -- & -- & 3 & 4 & -- & 2 & 1 & -- & -- & -- & 10 \\
\hline 17 & A. immaculifrons & -- & -- & 2 & 1 & 2 & -- & -- & -- & -- & -- & -- & -- & 05 \\
\hline 18 & R.quadrimaculata & -- & -- & -- & -- & 1 & 2 & -- & 3 & 4 & -- & -- & -- & 10 \\
\hline 19 & R. bisignata & -- & -- & -- & -- & 2 & 1 & -- & 1 & 1 & -- & -- & -- & 05 \\
\hline 20 & I. aurora & -- & -- & -- & -- & -- & 5 & 4 & 2 & 1 & -- & -- & -- & 12 \\
\hline 21 & C.coromandelianum & -- & -- & -- & -- & 5 & 3 & 2 & 2 & 3 & -- & -- & -- & 15 \\
\hline 22 & C. olivaceum & -- & -- & -- & -- & -- & 3 & 2 & 4 & 1 & -- & -- & -- & 10 \\
\hline Total & & -- & -- & 2 & 6 & 42 & 33 & 18 & 49 & 46 & 04 & -- & -- & 200 \\
\hline
\end{tabular}

apple green damselfly having black stripes on its thorax and blue tipped yellow tail. Males are brightly colored while the females have dull coloration. The highest abundance of the odonates was recorded in August, September and May while no odonate species were detected in January, February, November and December (as shown in Table 2). Reasons for the low diversity in the specific months are the unfavorable climatic conditions which restricts the increase in populations of insect fauna. Lotic water bodies were dominated by odonates followed by lentic water bodies while the least number of odonate species was recorded in hilly areas with scarce water bodies (as shown in Table 3).

A diverse fauna of Odonata was recorded in the present study as indicated by the values of Shannon Diversity Index $(\mathrm{H}=2.988)$ and Simpson Diversity Index $(\mathrm{D}=0.95)$ (as shown in Table 4). A total of 12 genera of odonates were recorded in the present study with Orthetrum as the highest prevalent genus having a relative abundance of $36.6 \%$ and the genera Paragompus and Rhyothemis were the least abundant species having relative abundance of $2.5 \%$ each (as shown in Table 5). Overall, 22 species of odonates were recorded in the present study from diverse habitats with Pantala flavescens (Libellulidae: Anisoptera) as the most abundant species (as shown in Table 1). Morphometrics of the collected specimens showed that Anax immaculifrons was large sized odonate species having a wingspan $(53.2 \pm 1.63 \mathrm{~mm})$ and body length ( $56.3 \pm 0.4 \mathrm{~mm}$ ) (as shown in Table 1 ).

Shannon diversity index $(\mathrm{H})$ is given by the formula 1 :

$$
H=-\Sigma(P i) \times \ln (P i)
$$

Where $\mathrm{P} i$ is the proportion of individuals of a given species and $\ln$ stands for natural $\log$. In the present study, $\mathrm{H}=-(-2.988)=2.988$

Simpson diversity index (D) is calculated by the given formula 2 :

$$
D=1-\left[\frac{\Sigma n(n-1)}{N(N-1)}\right]
$$

Where " $n$ " is the total no of organisms of a given species while "N" is the total number of organisms of all species. In the present study, $D=1-[1966 / 200(200-1)]=1-0.049=0.95$

\section{Discussion}

The present study was conducted to evaluate the diversity of the suborders Anisoptera and Zygoptera of 
Table 3. Habitat distribution of the odonate fauna of Swat, Pakistan.

\begin{tabular}{|c|c|c|c|c|c|c|c|c|c|}
\hline S.No. & Species & $\begin{array}{c}\text { Lotic } \\
\text { waters }\end{array}$ & $\begin{array}{l}\text { Lentic } \\
\text { waters }\end{array}$ & Marshes & Swamps & Vegetation & $\begin{array}{c}\text { Rice } \\
\text { fields }\end{array}$ & $\begin{array}{l}\text { Hilly } \\
\text { areas }\end{array}$ & Total \\
\hline 1 & P. lineatus & 03 & 02 & -- & -- & -- & -- & -- & 05 \\
\hline 2 & A. panorpoides & -- & 05 & 03 & -- & 02 & -- & -- & 10 \\
\hline 3 & O. triangulare & 06 & -- & -- & -- & -- & -- & 04 & 10 \\
\hline 4 & O. pruinosum & 07 & 05 & -- & -- & 03 & -- & -- & 15 \\
\hline 5 & o. testaceum & 05 & 02 & 03 & -- & -- & -- & -- & 10 \\
\hline 6 & O. luzonicum & -- & -- & 05 & 03 & -- & 02 & & 10 \\
\hline 7 & O. cancellatum & 06 & 03 & -- & -- & -- & -- & -- & 09 \\
\hline 8 & O. sabina & 03 & 04 & -- & -- & 02 & -- & 01 & 10 \\
\hline 9 & P. flavescens & 05 & 03 & 02 & 04 & 03 & 01 & 02 & 20 \\
\hline 10 & T. aurora & 02 & 01 & & 01 & 01 & -- & -- & 05 \\
\hline 11 & P. sexmaculata & -- & -- & 05 & 03 & -- & 02 & -- & 10 \\
\hline 12 & R. variegate & -- & 03 & -- & -- & 01 & 01 & -- & 05 \\
\hline 13 & T. festiva & 03 & -- & -- & 02 & -- & -- & -- & 05 \\
\hline 14 & O. taeniolatum & 02 & 02 & -- & -- & 01 & -- & -- & 05 \\
\hline 15 & O. glaucum & 01 & 01 & 01 & -- & 01 & -- & -- & 04 \\
\hline 16 & C. servilia & 04 & 05 & -- & -- & -- & 01 & -- & 10 \\
\hline 17 & A. immaculifrons & 02 & 01 & -- & -- & 01 & & 01 & 05 \\
\hline 18 & R.quadrimaculata & -- & -- & -- & -- & 04 & 03 & 03 & 10 \\
\hline 19 & R. bisignata & 02 & -- & -- & -- & 02 & -- & 01 & 05 \\
\hline 20 & I. aurora & 04 & 03 & -- & 03 & 01 & -- & 01 & 12 \\
\hline 21 & C.cormandelianum & -- & 06 & -- & -- & 07 & 02 & -- & 15 \\
\hline \multirow[t]{2}{*}{22} & C. olivaceum & 04 & -- & -- & -- & 03 & 03 & -- & 10 \\
\hline & Total & 59 & 46 & 19 & 16 & 32 & 15 & 13 & 200 \\
\hline
\end{tabular}

the order Odonata (Insecta) of Swat, Pakistan. A total of 22 species were identified belonging to 12 genera and 5 families and 2 suborders of the Order Odonata. Suborder Anisoptera comprised 74\% $(n=148)$ while suborder Zygoptera comprised 26\% ( $n=52$ ) of the odonate species with family Libellulidae the largest family. This pattern conforms to the overall abundance and diversity of odonate fauna worldwide as is evident from a recent report on the odonate fauna of Brazil (Garcia Junior et al., 2021). Some of the successful traits that make family Libellulidae the dominant family in diverse habitats worldwide include their ability to efficiently control their body temperature (Corbet \& May 2008), adaptation to open vegetation environments (Rodrigues \& Roque 2017), survival in human dominated habitats (Damaceno et al. 2014) and a great dispersion potential (Oliveira-Júnior et al. 2017). The families Gomphidae and Aeshnidae of the suborder Anisoptera were the least abundant families of the Order Odonata. Some of the reasons for the low number of these families include their crepuscular nature and their fast-flying potential at higher altitudes (Bedê et al. 2000) which makes them difficult to be captured uniformly with the conventional collection methods.
The family Coenagrionidae of the suborder Zygoptera was the abundant family ( $\mathrm{n}=37$ ) with three identified species followed by Chlorocyphidae $(n=15)$ with two identified species. Zygopterans are mostly habitat specific representing peculiar habitats and are not dominant in diverse habitats like Anisoptera. This property makes them less diverse and resultantly leads to less catch during various sampling techniques. The less abundance of the species of Zygoptera can be attributed to their small sizes and the resultant restrictions to habitats with less temperature fluctuations and less exposure to sunlight (Brasil et al. 2019).

Abundant species of Anisoptera were Pantala flavescens and Orthetrum pruinosum while in Zygoptera, Ceriagrion coromandelianum was the most dominant species in District Swat, Pakistan representing maximum number of specimens found in diverse habitats ranging from lotic to lentic water bodies, hilly areas, marshes, running streams, grasslands, rice lands and swampy areas. The species $P$. flavescens was collected almost from all surveyed habitats.

The variations among different reports are because of the different ecological, climatic and topographic conditions of the study areas along with differences in the sampling techniques. Overall, odonate fauna is diverse in habitats 
Table 4. Shannon and Simpson diversity indices of the odonate fauna of Swat, Pakistan.

\begin{tabular}{|c|c|c|c|c|c|c|}
\hline S.No. & Species & Number (n) & $\mathbf{P} i$ & $\ln (\mathbf{P} i)$ & $\mathbf{P} i \times \ln (\mathbf{P} i)$ & $n(n-1)$ \\
\hline 1 & P. lineatus & 05 & 0.025 & 3.688 & -0.092 & 20 \\
\hline 2 & A. panorpoides & 10 & 0.05 & 2.996 & -0.149 & 90 \\
\hline 3 & O. triangulare & 10 & 0.05 & 2.996 & -0.149 & 90 \\
\hline 4 & O. pruinosum & 15 & 0.075 & 2.590 & -0.194 & 210 \\
\hline 5 & O. testaceum & 10 & 0.05 & 2.996 & -0.149 & 90 \\
\hline 6 & O. luzonicum & 10 & 0.05 & 2.996 & -0.149 & 90 \\
\hline 7 & O. cancellatum & 9 & 0.045 & 3.101 & -0.139 & 72 \\
\hline 8 & O. sabina & 10 & 0.05 & 2.996 & -0.149 & 90 \\
\hline 9 & P. flavescens & 20 & 0.1 & 2.302 & -0.230 & 380 \\
\hline 10 & T. aurora & 05 & 0.025 & -3.688 & -0.092 & 20 \\
\hline 11 & P. sexmaculata & 10 & 0.05 & 2.996 & -0.149 & 90 \\
\hline 12 & R. variegate & 05 & 0.025 & 3.688 & -0.092 & 20 \\
\hline 13 & T. festiva & 05 & 0.025 & 3.688 & -0.092 & 20 \\
\hline 14 & O. taeniolatum & 05 & 0.025 & 3.688 & -0.092 & 20 \\
\hline 15 & O. glaucum & 04 & 0.02 & 3.912 & -0.078 & 12 \\
\hline 16 & C. servilia & 10 & 0.05 & 2.996 & -0.149 & 90 \\
\hline 17 & A. immaculifrons & 05 & 0.025 & 3.688 & -0.092 & 20 \\
\hline 18 & R. quadrimaculata & 10 & 0.05 & 2.996 & -0.149 & 90 \\
\hline 19 & R. bisignata & 05 & 0.025 & 3.688 & -0.092 & 20 \\
\hline 20 & I. aurora & 12 & 0.06 & -2.813 & -0.168 & 132 \\
\hline 21 & C.coromandelianum & 15 & 0.075 & 2.590 & -0.194 & 210 \\
\hline 22 & C. olivaceum & 10 & 0.05 & 2.996 & -0.149 & 90 \\
\hline & Total & $N=200$ & $\Sigma(\mathrm{P} i)=1$ & -- & $\mathrm{H}=2.988$ & $\begin{array}{c}\Sigma \mathrm{n}(\mathrm{n}-1)=1966 \\
\mathrm{D}=0.95\end{array}$ \\
\hline
\end{tabular}

Table 5. Relative abundance of the recorded genera of odonate fauna of Swat, Pakistan.

\begin{tabular}{cccc}
\hline S No & Genera & $\begin{array}{c}\text { No. of } \\
\text { specimens (n) }\end{array}$ & $\begin{array}{c}\text { Relative } \\
\text { abundance (\%) }\end{array}$ \\
\hline 1 & Paragomphus & 05 & 2.5 \\
2 & Acisoma & 10 & 5 \\
3 & Orthetrum & 73 & 36.5 \\
4 & Pantala & 20 & 10 \\
5 & Trithemis & 10 & 5 \\
6 & Palpoplura & 10 & 5 \\
7 & Rhyothemis & 05 & 2.5 \\
8 & Crocothemis & 10 & 5 \\
9 & Anax & 05 & 2.5 \\
10 & Rhinocypha & 15 & 7.5 \\
11 & Ischnura & 12 & 6 \\
12 & Ceriagrion & 25 & 12.5 \\
Total & & 200 & $100 \%$ \\
\hline
\end{tabular}

with fresh and unpolluted water bodies encompassing rich vegetation.

The present study shows the status of odonate fauna of Swat, Pakistan with 22 species belonging to 5 families and 12 genera of the two suborders of Odonata, Anisoptera and Zygoptera. Decline in the odonate fauna compared with some of the previous reports like Chaudhry et al. (2016) and Zia et al. (2009) is indicative of the habitat degradation due to enhanced anthropogenic activities. Conservation measures are required to protect the diversity of these important biological control agents in diverse ecosystems. Further work is recommended on odonate adults as well as naiads and allied insect fauna of the study area to bridge the gaps found in the existing literature for future planning and conservation measures.

\section{References}

BEDÊ, L.C., PIPER, W., PETERS, G. and MACHADO, A.B.M., 2000. Phenology and oviposition behaviour of Gynacantha bifida Rambur in Brazil (Anisoptera: aeshnidae). Odonatologica, vol. 29, pp. 317-324. 
BOYD, S., 2005. Damselflies and dragonflies. Scientific Illustration Major. Athens: University of Georgia.

BRASIL, L.S., SILVERIO, D.V., CABETTE, H.S.R., BATISTA, J.D., VIEIRA, T.B., DIAS-SILVA, K., OLIVEIRA-JUNIOR, J.M.B., CARVALHO, F.G., CALVÃO, L.B., MACEDO, M.N. and JUEN, L..R., BATISTA, J.D., VIEIRA, T.B., DIAS-SILVA, K. and JUEN, L., 2019. Net primary productivity and seasonality of temperature and precipitation are predictors of the species richness of the Damselflies in the Amazon. Basic and Applied Ecology, vol. 35, pp. 45-53. http:// dx.doi.org/10.1016/j.baae.2019.01.001.

CHAUDHRY, M.T., MOHSIN, A., SHAHEEN, F.A., ARSHAD, M. and ZIA, A., 2016. Dragonflies (Odonata: Anisoptera) of Pakistan. Pakistan Journal of Zoology, vol. 48, no. 6, pp. 1957-1962.

CLARK, T.E. and SAMWAYS, M.J., 1996. Dragonflies (Odonata) as indicators of biotope quality in the Kruger National Park, South Africa. Journal of Applied Ecology, vol. 33, no. 5, pp. 1001-1012. http://dx.doi.org/10.2307/2404681.

CORBET, P.S. and MAY, M.L., 2008. Fliers and perchers among Odonata: dichotomy or multidimensional continuum? A provisional reappraisal. International Journal of Odonatology, vol. 11, no. 2 , pp. 155-171. http://dx.doi.org/10.1080/13887890.2008.9748320.

DAMACENO, I.V., BUYS, S.C., SILVA, C.C. and MARTINS, R.F., 2014 Levantamento de Odonata (Insecta) ao longo das margens do Rio DoisSetembro, Município de Ecoporanga, noroeste do Estado do Espirito Santo. Boletim do Museu Mello Leitão, vol. 33, pp. 25-33.

DEMARCO JUNIOR, P. and RESENDE, D.C., 2002. Activity patterns and thermoregulation in a tropical dragonfly assemblage. Odonatologica, vol. 31, no. 2, pp. 129-138.

DIN, A.U., ZIA, A., BHATTI, A.R. and KHAN, M.N., 2013. Odonata Naiads of Potohar Plateau, Punjab, Pakistan. Pakistan Journal of Zoology, vol. 45, no. 3, pp. 695-700.

FAZLULLAH, M.S., ZIA, A., FARID, A., MASAUD, S., KHAN, T.B. and ZADA, N., 2016. Libellulidae (Anisoptera) of upper Swat, Khyber Pakhtunkhwa Pakistan. Journal of Entomology and Zoology Studies, vol. 4, pp. 227-228.

FRASER, F.C., 1933. The Fauna of British India including Ceylon and Burma: Odonata. London: Taylor and Francis, vol. 1-3.

GARCIA JUNIOR, M.D.N., DAMASCENO, M.T.S., MARTINS, M.J.L., COSTA, T.S., FERREIRA, R.M.A. and SOUTO, R.N.P., 2021. New records of dragonflies and damselflies (Insecta: Odonata) from Amapá state, Brazil. Biota Neotropica, vol. 21, no. 1, pp. e20201074. http://dx.doi.org/10.1590/1676-0611-bn-2020-1074.

ILAHI, I., YOUSAFZAI, A.M., ATTAULLAH, M., HAQ, T., ALI, H., RAHIM, A. and AHMAD, A., 2019. The role of odonate nymphs in ecofriendly control of mosquitoes and sensitivity of odonate nymphs to inorganic nutrient pollutants. Applied Ecology and Environmental Research, vol. 17, no. 3, pp. 6171-6188. http:// dx.doi.org/10.15666/aeer/1703_61716188.

IRSHAD, M., 2008. Biological control of insects and weeds in Pakistan. Pakistan: Higher Education Commission of Pakistan.

JOHARI, P.R. and JAIN, N., 2021. Comparative study of odonates in two selected sites (Umed Ganj and Chatra Vilas garden) of Kota, Rajasthan (India). Journal of Entomology and Zoology Studies, vol. 9, no. 1, pp. 930-933.

JOHNSON, N.F. and TRIPLEHORN, C.A., 2005. Borror and DeLong's introduction to the study of insects. Belmont: Thompson Brooks/ Cole. 864 p.
KNIGHT, A.L. and LARSEN, T.E., 2004. Improved deposition and performance of a microencapsulated sex pheromone formulation for codling moth (Lepidoptera: Tortricidae) with a low volume application. Journal of the Entomological Society of British Columbia, vol. 101, pp. 79-86.

MITRA, T.R., 2002. Endemic Odonata of India. Records of the Zoological Survey of India, vol. 100, no. 3-4, pp. 189-199.

NAIR, M.V., 2011. Dragonflies \& Damselflies of Orissa and Eastern India. India: Wildlife Organisation, Forest \& Environment Department, Government of Orissa.

OLIVEIRA-JUNIOR, J.M.B., DE MARCO, P., DIAS-SILVA, K., LEITÃO, R.P., LEAL, C.G., POMPEU, P.S., GARDNER, T.A., HUGHES, R.M. and JUEN, L.. 2017. Effects of human disturbance and riparian conditions on Odonata (Insecta) assemblages in eastern Amazon basin streams. Limnologica, vol. 66, pp. 31-39. http://dx.doi. org/10.1016/j.limno.2017.04.007.

PERVEEN, F., KHAN, A. and RAUF, S.A., 2014. Key for first recorded dragonfly (Odonata: Anisoptera) fauna of district lower Dir, Khyber Pakhtunkhwa, Pakistan. Insects Rev, vol. 1, no. 2, pp. 26-35.

RAFI, M.A., KHAN, M.R., ZIA, A. and SHEHZAD, A., 2009. Diversity of Odonata in district Poonch and Sudhnoti of Kashmir ValleyPakistan, with a new record for the country. Halteres, vol. 1, no. 1, pp. 28-35.

RODRIGUES, M.E. and ROQUE, F.O., 2017. Checklist de Odonata do Estado de Mato Grosso do Sul, Brasil. Iheringia. Série Zoologia, vol. 107, supl., pp. 107-111. http://dx.doi.org/10.1590/1678$4766 \mathrm{e} 2017117$.

SAMWAYS, M.J. and STEYTLER, N.S., 1996. Dragonfly (Odonata) distribution patterns in urban and forest landscapes, and recommendations for riparian management. Biological Conservation, vol. 78, no. 3, pp. 279-288. http://dx.doi. org/10.1016/S0006-3207(96)00032-8.

SUHONEN, J., KORKEAMÄKI, E.S.A., SALMELA, J. and KUITUNEN, M., 2014. Risk of local extinction of Odonata freshwater habitat generalists and specialists. Conservation Biology, vol. 28, no. 3, pp. 783-789. http://dx.doi.org/10.1111/cobi.12231. PMid:24405332.

TRUEMAN, J.W.H. and ROWE, R.J., 2009. [viewed 7 May 2021]. Odonata. Dragonflies and Damselflies. Version 16 October 2009 [online]. The Tree of Life Web Project. Available from: http:// tolweb.org/Odonata/8266/2009.10.16

WILLIGALLA, C. and FARTMANN, T., 2012. Patterns in the diversity of dragonflies (Odonata) in cities across Central Europe. European Journal of Entomology, vol. 109, no. 2, pp. 235-245. http://dx.doi. org/10.14411/eje.2012.031.

ZIA, A., RAFI, M.A., HUSSAIN, Z. and NAEEM, M., 2009. Occurrence of Odonata in northern area of Pakistan with seven new records. Halteres, vol. 1, no. 1, pp. 48-56.

ZIA, A., NAEEM, M., RAFI, M.A., NAZ, F., AFSHEEN, S. and ILYAS, M., 2011. Damselflies (Zygoptera: Odonata) of Pakistan: Part 1. Journal of Insect Science, vol. 11, no. 1, pp. 102. http://dx.doi. org/10.1673/031.011.10201. PMid:22221175.

ZIA, A., HUSSAIN, I., MEHMOOD, S.A., AHMAD, S., SHAH, M. and BHATTI, A.R., 2019. Richness and distribution of Odonata in Kurram district, Khyber Pakhtunkhwa. Pakistan Journal of Agricultural Research, vol. 32, no. 4, pp. 589. http://dx.doi. org/10.17582/journal.pjar/2019/32.4.589.594. 